\title{
MENGGUGAT NALAR FIQH PESANTREN
}

\author{
Habibullah Bahwi \\ (F akultas U shuluddin UIN Sunan Kalijaga JI. Laksda A disucipto \\ Y ogyakarta, email: nyokbungsoh@yahoo.com)
}

\begin{abstract}
A bstrak:
Fiqh merupakan produk ijtihâd yang digali dari al-Qur'ân, Hadîts, ijmâ' dan qiyâs. Dalam proses penggaliannya, fiqh menggunakan metodologi ushûl figh sehingga menghasilkan ketetapan hukum Islâm yang didasarkan pada otoritas nash dan kekuatan nilai-nilai tujuan syara', yaitu mendatangkan kemaslahatan dan menghilangkan kemudharatan. Namun demikian, figh pesantren -pada tulisan ini mendapat kajian khusus- merupakan salah satu produk figh masyarakat pesantren yang terlahir dari nalar perspektif mereka yang sangat verbalistik dan tercerabut dari dari akar metodologisnya. Karena itu, proses penggaliannya perlu dikembalikan pada idealisme pembentukan figh yang sesungguhnya agar menjadi produk figh yang dapat menyelesaikan problematika umat secara universal sertat menjawab tuntutan zaman dan teknologi.
\end{abstract}

\section{Kata Kunci:}

Nalar, kritis, figh, dan pesantren.

\begin{abstract}
A bstract:
Fiqh (Islamic study of law) has been the product of ijtihâd (scholar interpretation) and it has been based on al-Qur'ân (Islamic holy scripture), Hadîts (deeds of prophet), ijmâ' (scholar consensus of opinion), dan qiyâs (deductive analogy). In its establisment process, figh applies the methodology of ushûl alfigh (the origin of Islamic law) resulting Islamic law decisions on the basis of nash (quotation) authority and the power of syara' objective values---to call up benefit and to miss out the disadvantages. However, fiqh pesantren (Islamic boarding school), the focus of this study, is born from the logical reasoning of pesantren community that is too verbalistic and is lifted out from its methodology root. Hence, it is urgent to take it back to the idealism of the true figh compilation. Its aims are to handle th problem of umat (religious coomunity) universally and to response the pursuit of technology and epoch.
\end{abstract}


Habibullah Bahwi

\section{Key Words:}

logical reasoning, critical, fiqh, and pesantren

\section{Pendahuluan}

Fiqh merupakan kajian keislaman yang paling dominan di pondok pesantren. Kajian semacam ini begitu mengakar dan mendarah daging sehingga tawaran-tawaran solutif terhadap problem yang tengah dihadapi umat lebih berorientasi pada produk figh. Figh pesantren memiliki karakteristik dan keunikan sendiri. Tradisi yang mengakar biasanya santri disiapkan aspek keilmuan bahasanya sebelum mengkaji figh dalam beberapa literatur figh klasik. Hanya saja, pengembangan keilmuan figh di kalangan mereka lebih berorientasi pada figh sentris dan kajiannya sangat verbal istik. Karena itu, dapat diasumsikan bahwa persoalan yang dikaji oleh komunitas pesantren seakan-akan hanya didasarkan pada persoalan hitamputih, boleh-tidak boleh, halal dan haram berdasar temuan mereka pada literatur-literatur yang dikaji.

Kondisi ini telah membentuk watak dan karakter keagamaan tersendiri bagi kaum santri dan bahkan telah mengarahkan kesadaran keislaman mereka pada satu paradigma figh sehingga pesantrenpesantren yang ada di Indonesia mayoritas menganut salah satu aliran figh tertentu dari empat madzhab figh. Ini dapat dibuktikan bahwa referensi-referensi kitab-kitab figh madzhab Syâfi'î merupakan referensi paling banyak dirujuk sebagai rujukan utama dalam pemecahan kasus-kasus hukum Islâm

\section{V erbalistik: Tradisi Berfikir M asyarakat Pesantren}

Tradisi intelektual dan pengembangan hukum Islâm di lingkaran pesantren dapat dengan mudah diamati melalui pola-pola kajian yang diterapkan di sana, dimana kebanyakan para ulama hanya mampu mengurai secara verbal (kata demi kata) tanpa pernah berani mencoba menganalisanya secara kritis-apalagi benar-benar mengkritisinya - , sehingga terkesan menjadi muqallid yang menerima dan mengikuti begitu saja ajaran teoritis teks-teks karya ulama sebelumnya.

Munculnya sikap semacam ini sebetulnya merupakan dampak implikatif dari adanya reaksi yang berlebihan terhadap produk 
pemikiran ulama sebelumnya yang telah dianggap sempurna, tidak perlu ditinjau ulang dan dikritisi kembali. A sumsi tersebut berangkat dari anggapan dasar bahwa pekerjaan untuk menafsirkan dan mengembangkan hukum Islâm telah paripurna dilakukan ulama terdahulu yang tidak tertandingi, suatu hal yang memperkuat anggapan bahwa syari'at telah sampai pada format yang final dan sempurna.

Tradisi taqlîd dalam konteks pemaknaan hukum Islâm terjadi dalam setiap generasi, sesuai dengan tingkat kemampuannya dalam memahami sumber hukum itu sendiri. Dalam hal ini, gambaran struktur kronologisnya dapat dibagi menjadi tiga peringkat kemampuan dan kreatifitas intel ektual; pertama adalah para mujtahid yang menafsirkan hukum Islâm langsung dari sumbernya. Kedua adalah para muttabi' yaitu kelompok yang mengikuti para mujtahid dengan mengetahui kerangka konseptual dan sumbernya. Dan ketiga adalah muqallid yaitu kelompok yang mengikuti secara membabi buta pendapat dan teori-teori ulama sebelumnya tanpa meneliti ulang kebenaran dan kesesuaiannya dengan realitas kekinian. Dengan demikian, maka penggunaan istilah taqlîd di sini dapat dimaknai sebagai hilangnya kreatifitas para ahli figh terhadap pemaknaan dan pengembangan hukum Islâm itu sendiri' ${ }^{1}$. Kenyataan seperti inilah yang menjadi gejala umum di lingkungan pesantren kita. Melalui gambaran singkat di atas, setidaknya kita sudah bisa menerka atau minimal meng-abstraksikan fungsi signifikan dari hermeneutika sebagai kerangka metodologis dalam mengkaji teks dan teori hukum Islâm yang ada. Ini tidak jauh berbeda dari penjelasan sebelumnya, mengenai problem epistemologi pesantren dalam memahami literatur-literatur figh sebagai produk "pengetahuan".

\section{Fiqh Pesantren: Tercerabut dari A kar M etodologisnya}

Secara historis, perkembangan studi-studi hukum Islâm tidak hanya terbatas pada satu perspektif. Biasanya, nalar yang dibangun dalam proses pembentukan hukum Islâm tidak kemudian terlepas dari nalar pengetahuan lainnya, seperti logika ushûl figh, ilmu teologi, antropologi sosial, maupu ilmu hikmah.

1 Khudori Bik, Târîkh al-Tasyrî' al-Islâmi, (Surabaya: Muhammad bin Ahmad bin Nabhan wa Awladuhu, tt.), hlm 323. 
Keterkaitan beberapa disiplin ilmu tersebut bisa kita amati melalui latar belakang sejarah tradisi pemikiran Islâm. Secara historis, pertentangan teologis merupakan problem dasar yang melatarbelakangi munculnya faksi-faksi pemikiran dalam Islâm, yakni bermula dari perang paradigma antar kepentingan dan pemahaman pasca-meninggalnya Rasûlullâh hingga mencapai puncaknya pada perang epistemik dan ideologis antar aliran, seperti yang terjadi antara gololongan Jabariyah, Murji'ah, Qadariyah, Mu'tazilah, Sunni dan Syî'ah. Pertentangan tersebut merupakan cikalbakal lahirnya madzhab-madzhab hukum dalam Islâm.

Munculnya persoalan-persoalan baru memaksa mereka merumuskan metodologi istinbât hukum melalui ijtihâd dan konsensus, dengan tetap merujuk pada kerangka dasar yang telah ditentukan oleh al-Qur'ân dan al-sunnah. Di sini tampak bahwa dialektika pemahaman antara para filosof, mutakallimîn, fuqahâ' dan para sufi terjadi dan saling melengkapi satu sama lain sehingga dialektika pemahaman tersebut mengantarkan umat Islâm menuju puncak kecemerlangan ilmu pengetahuan dan peradabannya.

Dalam figh Islâm terdapat logika abadi yang merujuk langsung pada ajaran al-Qur'ân dan Sunnah yang diistilahkan sebagai tujuantujuan umum syarî'ah Islâm. Secara tidak langsung, logika tersebut meniscayakan adanya penafsiran ulang yang berkelanjutan untuk dapat merespons dan memberikan solusi terhadap setiap perubahan yang terjadi, namun kenyataan dalam tradisi kajian hukum Islâm yang berkembang di pesantren, justru malah menghindar dari logika lingkaran ini. A khirnya, perangkat metodologis yang sudah tersedia sebelumnya tidak berfungsi yang berakibat pada kurang berkembangnya studi-studi hukum Islâm. Akhirnya, produk fiqh hanya berputar-putar dalam lingkaran produk teoritik semata karena terlalu terpaku pada teori-teori normatif hasil pemikiran ulama' sebelumnya. Fenomena seperti ini tampak jelas dari sikap pasif dan kecenderungan apologetis para pakar figh pesantren ketika dihadapkan pada persoalan-persoalan baru yang tidak ada rujukannya dalam kitab-kitab figh klasik.

Di samping itu, tersumbatnya nalar kritis disebabkan oleh adanya pensakralan dan menonjolnya sikap fanatisme terhadap madzhab yang dianutnya, yang pada akhirnya berakibat pada 
kebiasaan truth claim sekaligus mandeknya kreativitas intelektual para santri dalam memahami realitas hukum Islâm yang sesungguhnya. Ini terbukti dari sangat dominannya dalil-dalil teoritis dari pada pendekatan metodologisnya sehingga sumber utama hukum Islâm, yaitu al-Qur'ân dan al-sunnah-seakan-akanmenempati posisi nomor dua setelah kitab-kitab figh madzhab dalam pemecahan kasus-kasus hukum tertentu.

\section{N alar Kritis: Paradigma Baru Fiqh Pesantren}

Dalam studi filsafat, kesalahan epistemologis berarti sebuah kecelakaan intelektual. Karenanya, persoalan epistemologi ini selalu menjadi pusat perdebatan sengit di mana validitas dan kebenaran sebuah pengetahuan dipertaruhkan. Dalam struktur ilmu pengetahuan, problem ini (epistemologi) tidak terbatas pada ruangruang disiplin keilmuan tertentu, melainkan mencakup seluruh disiplin keilmuan yang ada tanpa terkecuali disiplin ilmu figh sebagai salah satu sistem pengetahuan dan hukum dalam Islâm.

Persoalan dominan yang menjadi bidikan utama epistemologi, adalah meliputi seluruh aspek yang mendasari "proses" lahirnya sebuah pengetahuan (teori-teori ilmu pengetahuan), mulai dari hakikat pengetahuan, sumber pengetahuan dan cara memperoleh pengetahuan berikut validitas kebenarannya. Itulah sebabnya, persoalan ini menjadi pra-syarat utama bagi setiap pembahasan mengenai produk pengetahuan yang dihasilkan oleh manusia. Karena, tanpa Iandasan epistemologis yang kuat, "pengetahuan" justeru akan melahirkan sebuah pemahaman yang rancu, mengambang dan sulit untuk dijelaskan, di samping juga akan beraki bat terhadap timbulnya kesalah-pahaman yang fatal khususnya dalam penerapannya (aksiologinya). Makanya, persoalan ini merupakan bagian sangat penting dalam kajian figh, karena sesuai dengan pengertian terma awalnya bahwa figh itu sendiri merupakan "pengetahuan dan pemahaman". Itulah sebabnya, mengapa dalam kajian-kajian ushul fiqh yang ada sarat dengan istilah proses dan tujuan pengetahuan.

Dalam konteks ini, terputusnya siklus suatu sistem pengetahuan merupakan bukti dari rapuhnya bangunan epistemologi 
di dalamnya. Akan tetapi tidak semua tradisi keilmuan yang mandek diakibatkan oleh hal ini, yakni masi h ada kemungkinan lain yang juga dapat mengakibatkan terputusnya siklus sebuah tradisi keilmuan,bisa saja - meskipun bangunan epistemologinya kuat namun tetap saja "mandek" dan tidak berkembang sebagaimana mestinya, diakibatkan oleh keberadaannya (epistemologi yang terbangun di dalamnya) telah terabaikan dan kurang dimengerti sebagai persoalan dasar yang harus dipahami. Contoh paling sederhana dari terabaikannya persoalan ini (epistemologi) di lingkungan pesantren dalam mengkaji disiplin ilmu fiqh adalah; ketergantungan yang sangat berlebihan terhadap realitas teks yang sedang dikaji, fakta ini tampak dari sekian pola pemecahan masalah yang mentradisi dalam diskusi-diskusi harian para santri, di mana dalil (teks) selalu menjadi justifikasi akhir terhadap keputusan hukum yang diambil.

$\mathrm{Hal}$ inilah yang pernah digelisahkan oleh $\mathrm{KH}$. Abd. Wahid Zaini. Menurutnya, wacana figh yang berkembang di pondok pesantren saat ini sungguh telah mengalami reduksi yang sangat drastis, apalagi kalau dikembalikan ke masa Nabi. Reduksi tersebut lebih-lebih dijustifikasi dengan hadirnya pembatasan pada kitab-kitab yang boleh dibaca karena kualifikasinya memenuhi syarat yang sampai saat ini belum jelas rujukan kriteria ataupun sumber munculnya pembatasan tersebut. M odel dan tradisi yang berkembang ini tentunya membiasakan kalangan pesantren untuk terfokus pada pemahaman teks dan pengembangan pemahaman teks figh dalam kitab-kitab kuning. Sedangkan bagaimana aplikasi pemahaman tersebut dalam realitas empirik, dan keutuhan perspektif permasalahan dari sudut selain figh tentunya menjadi permasalahan tersendiri yang selama ini belum mendapat perhatian. Ini misalnya terlihat di dalam tradisi kajian yang sangat berkembang di pesantren selama ini, di mana pengkajian masalah yang bahkan dilakukan secara kolektif dalam sebuah forum (bahts al-masâ'il) adalah sekedar mencari rujukan tekstual bagi kasus yang ditemui2.

Kebiasaan tekstual seperti di atas menunjukkan bahwa nalar kritis dan kreatifitas intelektual pesantren, tidak berkembang

2 KH. A bd Wahid Zaini, dalam A bd Hamid Wahid dan N ur Hidayat (ed), Perspektif Baru Pesantren dan Pengembangan M asyarakat, (Surabaya: Yayasan Triguna Bhakti, 2001), hIm 10-15. 
sebagaimana harusnya, mandek dan terjebak dalam lingkaran teksteks yang ada. Sehingga dengan demikian, bisa diduga, pondok pesantren sebagai lembaga pendidikan Islâm yang terbesar di Indonesia, sampai kapanpun tidak akan pernah mampu melahirkan para mujtahid dan mujaddid yang dinamis, kreatif dan bermutu, apalagi yang benar-benar mampu memahami sistem hukum Islâm yang sesuai dengan kondisi masyarakatnya. Untuk itu, ada beberapa hal yang perlu digarisbawahi oleh komunitas pesantren dalam membentuk sistem kajian yang sehat dan produktif mengenai pola kajian ilmu figh sebagai produk pemikiran manusia, diantaranya adalah membangun kesadaran kritis para santri bahwasanya teoriteori hukum figh madzahib (termasuk teori ushul figh) yang terangkum dalam berjilid-jilid kitab klasik itu merupakan hasil kerjakerja intelektual para imam zaman dulu yang tidak sepenuhnya sempurna, karenanya, kesalahan epistemik mungkin saja terjadi dalam proses penafsiran, penulisan dan kerangka metodologisnya, sehingga secara teoritik, tentu saja, boleh untuk dikritik, berubah dan dirubah.

Meninggalkan pola-pola lama yang kurang ilmiah dalam sistem kajian dan pembelajaran hukum Islâm di lingkungan pesantren, sehingga keterjebakan pada pembahasan hal-hal yang tidak perlu bisa segera ditinggalkan, yakni, kebiasaan mempersoalkan masalah-masalah yang parsial dan kurang tepat sasaran; seperti tentang bagaimana hukumnya menjual kotoran sapi, naik unta yang meminum khamr, memakan daging binatang yang proses penyembelihannya dilakukan dengan menggunakan mesin dan lainlain. Seharusnya sudah memulai berpikir lebih luar berkait dengan munculnya tantangan yang lebih konpleks sesuai perkembangan dan teknologi.

Mentradisikan kajian-kajian yang lebih bersifat analitis dan observatif dengan menggunakan perangkat epistemologi dan metodologi terbaru yang sejalan dengan perkembangan ilmu pengetahuan, sains dan tekhnologi. Dengan cara ini, maka format kajiannya bisa diarahkan pada pola-pola riset dan hasilnya bisa disesuaikan dengan perkembangan ilmu pengetahuan dan tekhnologi sehingga para pakar figh pesantren tidak akan selalu kebingungan dengan lahirnya penemuan-penemuan baru di bidang tekhnologi 
Habibullah Bahwi

kedokteran, informatika dan yang lain. Dengan demikian, maka penggunaan epistemologi yang benar, secara otomatis, merupakan proses dan kerangka logik yang akan membawa pada pemaknaan dan pemahaman yang benar, begitu pun sebaliknya, penggunaan epistemologi yang salah dalam mengkaji ilmu figh akan membawa dampak terhadap kesalahpahaman, lebih-lebih, terhadap entitas maknawiyah produk hukum figh itu sendiri. Dalam hal ini, salah satu kesalahan epistemologis pesantren dalam memahami fiqh sebagai bagian dari disiplin ilmu keislaman, adalah karena orientasi pemahamannya yang terbatas pada eksistensi figh sebagai "produk" bukan "proses" sehingga bangunan epistemologinya hanya selesai pada batas kerangka teoritik hasil pemikiran sebelumnya. ${ }^{3}$ Padahal, seandainya mau kembali pada spirit ulama madzhab masa silam, proses pembaharuan dan pengembangan perangkat metodologi hukum Islâm mustinya terus-menerus harus dikembangkan dan ditingkatkan. Karena di wilayah inilah sebetulnya "nalar" hukum figh itu menentukan fungsi signifikannya dalam mengatur dan mengarahkan kesadaran ummat.

Di samping kajian epistemologis, mengkaji sebuah teks dapat dikaji secara hermeneutis4, karena mengkaji sebuah teks tidak bisa dilepaskan begitu saja dari realitas teks baik dari setting historis, problem linguistik, subyek maupun obyek teks itu sendiri. Sebab,

3 Kesalahan inilah yang mengakibatkan mand eknya aktivitas keilmuan hukum Islâm di lingkungan pesantren; warisan intelektual para shahabat dan para ulama terdahulu yang seharusnya dikembangkan mal ah dijadikan monoment sakral yang tidak bisa diganggu gugat, karena sudah terlanjur dianggap sebagai kesimpulan akhir yang paripurna, paten dan kebal terhadap arus perubahan zaman. A kibatnya, pengembangan hukum yang menjadi ruh bagi visi Islâm sebagai agama abadi tidak terlaksana dengan baik.

4Berasal dari istilah Yunani, hermeneutikos (penafsiran). Secara definitif, heremeneutika berarti ilmu dan teori tentang penafsiran yang bertujuan menjelaskan teks mulai dari ciri-cirinya, baik oby ektif (arti gramatikal kata-kata dan variasi-variasi historisnya), maupun subyektif (maksud pengarang). Dalam penggunaan klasik, istilah ini mengaau kepada penafsiran teks-teks Al-Kitab, tetapi juga teks-teks filosofis. Sementara, dalam filsafat ilmu-ilmu sosial terdapat pandangan bahwa metode ilmu-ilmu sosial lebih dekat dengan hermeneutika daripada ilmu-ilmu eksperimental. Sprenger, misalnya, memandang ilmu psikologi sebagai “hermeneutika roh". Lorens Bagus, kamus filsafat, (Jakarta: Gramedia, 1996), hlm. 283284. 
munculnya sebuah teks memiliki nalar dan latar belakang sejarah yang berbeda antara teks yang satu dengan teks yang lainnya. Ini menunjukkan bahwa setiap produk, apapun bentuknya, musti melewati serangkaian proses-sebuah keniscayaan kodratik yang tidak bisa dibantah oleh siapapun dan ilmu apapun. Untuk itu, kerangka metodologis yang tidak boleh ditinggalkan terutama ketika berhadapan langsung dengan realitas teks adalah kajian hermeneutik yaitu mengkaji kondisi eksternal maupun internal yang melatarbelakangi lahirnya sebuah teks, yaitu menyangkut setting historis berikut kondisi subyektif si pengarang teks itu sendiri.

Tawaran awal dari pengembangan studi hermeneutika ini, tidak lain ditujukan untuk membangun nalar kritis dan dinamis di lingkungan pesantren dalam mengkaji khazanah-khazanah tradisi pemikiran Islâm klasik yang kebanyakan terangkum dalam bentuk teks (kitab-kitab kuning), supaya paradigma sakral dan fanatisme terhadap hasil pemikiran ulama yang tercipta di sana dapat di letakkan pada porsi yang sebenarnya, tanpa harus merusak citra esensif produk tradisi pemikiran tersebut.

\section{Penutup}

Studi teks diperlukan perangkat epistemologis dan metodologis yang memadai untuk menghindari keterjebakan pemahaman dan supaya terhindar dari keterpakuan pemaknaan pada realitas tekstual semata. Sementara, dalam sistem pembelajaran dan studi-studi ilmu keislaman yang berjalan di pesantren. Kerangka metode hermeneutik ini kurang begitu diperhatikan sebagai perangkat metodologis yang sangat penting dalam mengkaji sebuah teks. Namun, lebih jauh dari itu, karena diakibatkan oleh beberapa hal, dan salah satu diantaranya adalah karena dikesampingkannya disiplin ilmu-ilmu lain yang terkait dengan sistem pemikiran dan pemahaman, seperti epistemologi, ilmu logika5, semantika6,

5 Logikos atau logike (Yunani), logic (Inggris), adalah teori mengenai syarat-syarat penalaran yang sah. Istilah ini digunakan pertama kali oleh Alexander dari A phrodisius (abad ke-2 M). Tilisan-tulisan Aristoteles mengenai Ilmu logika ini disebut Organon, atau instrumen ilmu. Penalaran bertolak dari satu atau lebih pernyataan yang disebut premis ke suatu pernyataan selanjutnya yang disebut kesimpulan; bila kesimpulan berasal dari premis-premis secara niscaya, proses itu disebut deduksi (penalaran deduktif, logika deduktif), namun bila kesimpulan itu 
semiotika7 dan hermeneutika, yang menurut sepengetahuan saya, kesemuanya itu merupakan bagian struktural dari frame besar filsafat. Dengan demikian, maka bisa dipahami bahwa konservatifisme pemahaman figh pesantren adalah karena rasa antipatinya terhadap hal-hal yang berbau filsafat beserta instrumen teoritik keilmuan lain yang menjadi bagiannya. Akhirnya, pemahaman keilmuan yang dihasilkannya pun cenderung kurang seimbang antara konteks, teks dan kontekstualisasinya ke dalam realitas nyata. Karena itu, memunculkan figh pesantren di masa depan yang lebih kritis dan metodologis merupakan suatu keniscayaan.

\section{D aftar Pustaka}

Bagus, Lorens. kamus filsafat. Jakarta, Gramedia, 1996.

Bik, Khudori. Tarikh at-Tasyri' al-Islami. Surabaya. Muhammad bin A hmad bin Nabhan Wa Auladuhu, t.t.

Hourani, Albert. Arabic Thought In The Liberal Age 1798-1939. (Cambridge: The Press Syndicate of The University of Cambridge.

Jabiri, Muhammad Abid Al-. Ad-Din Wa ad-Daulah Wa Tathbiq A sySyari'ah. Markaz Dirasat al-Wahdah Al-Arabiyyah, Beirut 1996.

berasal dari premis-premis dengan derajat kemungkinan, maka proses itu disebut induksi (penalaran induktif, logika induktif). Ibid, hIm 519-520.

Dalam tradisi pemikiran Islâm, logika ini banyak digunakan dalam disiplin ilmu kalam, ushul figh dan ilmu hitung, seperti astrologi dan astronomi.

6 Ilmu tentang hubungan simbol-simbol linguistik dengan hal-hal yang lain dari simbol-simbol itu sendiri dengan mengacu pada apa yang mereka artikan dan apa yang mereka acu. Ibid., hlm 981.

7 John Locke, menggunakan istilah ini (semiotika) untuk menunjuk pada suatu ilmu tentang tanda-tanda dan signifikasi, yang materi pokoknya adalah logika. Sementara Peirce mencirikan logika "dalam arti umumnya" sebagai "semiotic, doktrin tentang tanda-tanda yang formal atau kuasi niscaya", dengan membagi subjek itu ke dalam bahasa murni, logika, dan retorika murni. Ibid., hlm 958. 
Jameelah, Maryam (Margaret Marcus), Islam dan modernisme. Surabaya, Penerbit Usaha Nasional, 1982.

Jurjani, Syarif AI-. Kitab A I-T a'rifat. Beirut, Maktabah Lubnaniyyah, 1990).

Qardawi, Al-. Yusuf Membumikan Syari'at Islam. Surabaya, Media IImu.

Sa'doellah. A. “Pendidikan Cap Sarung; Wacana Keilmuan Pesantren, Nalar Kritis dan Kepekaan Social Santri. Jurnal Gerbang, Vol 06, N o.03, (Februari- Maret 2000).

Wahed, A. M enggerakkan Tadisi: Esai-esai Pesantren. Yogyakarta. LKiS, 2001.

Wahid, Abd Hamid Dan Nur Hidayat (ed), Perspektif Baru Pesantren Dan Pembangunan M asyarakat. Surabaya. Yayasan Triguna Bhakti, 2001.

Zuhri. S. Pendidikan pesantren di persimpangan jalan, (Jakarta, Buletin bina pesantren, Edisi A pril, 2000). 